International Journal of Engineering \& Technology, $7(2.24)(2018) 397-403$
International Journal of Engineering \& Technology
SPC
Website: www.sciencepubco.com/index.php/IJET
Research paper

\title{
Closed loop Fuzzy Logic Controlled Interleaved DC-to-DC converter Fed DC Drive System
}

\author{
R. Elavarasu ${ }^{1 *}$, C. Christober Asir Rajan ${ }^{2}$ \\ ${ }^{1,2}$ Department of Electrical and Electronics Engineering \\ ${ }^{1}$ Rajalakshmi Institute of Technology, Chennai, India \\ ${ }^{2}$ Pondicherry Engineering College, Pondy, India \\ *Corresponding Author Email: elava3000@gmail.com
}

\begin{abstract}
This paper deals with comparison of responses of PI and Fuzzy Logic controlled DC-to-DC converter Fed DC motor (FLCDDCDCM) systems. The DC input is converted into high frequency AC using full bridge inverter. The output is stepped up using a transformer and then it is rectified using voltage doubler rectifier. The open loop system with T filter at the output is simulated. The closed loop PI \& FLC based DDCDCM systems are designed, modeled and simulated using Matlab/Simulink. The time domain parameters of FL controlled system are compared with those of PI controlled system. The results indicated that FL controlled DDCDCM system has better response than PI controlled DDCDCM system.
\end{abstract}

Keywords: Fuzzy Logic Controller; PI Controller; DC-DC Converter

\section{Introduction}

SOLAR energy fluctuates during the day and vanishes at night Therefore, it cannot be considered as a steady energy source for the key load or the grid [1], [2]. However, a photovoltaic (PV)battery hybrid energy system can overcome the intermittent nature of solar energy and provide reliable power. This calls for two DC/DC converters or a three-port converter to interface the PV array, the battery, and the load. The conventional PV-battery hybrid system requires two individual converters. One converter is used to achieve the PV energy conversion and the other one is employed to charge or discharge the battery. This complex configuration contains many component numbers, increases the system volume and cost. Actually, the two individual converters can be replaced by a three-port converter to improve the power density.

A parallel structure of several individual bidirectional buck- boost converters is combined for multiport DC/DC conversion systems in [3] and [4]. However, the power devices cannot be shared by different individual converters. By employing the time-sharing control strategy, a multiple-input non isolated buck-boost converter and its isolated counterparts with unidirectional power flow are proposed in [5] and [6]. Furthermore, some improved multiple-input topologies with multidirectional energy conversion are introduced in [7]. These converters can be easily extended to any number of input ports. Unfortunately, the power devices and the magnetic components have to sustain the peak voltage and current stresses. And the output energy of each port is coupled and difficult to manage due to the times sharing control scheme. By integrating the half-bridge converter and the active-clamp forward converter, a tri modal half-bridge converter for a three-port interface is presented in [8] and [9]. The component numbers and the power losses can be saved for the power-harvesting systems.
However, the control variables of two duty cycles are interactional, which increases the control complexity. This concept can also be extended to four-port even higher port converters [10]. In addition, general rules are carried out to derive non isolated and isolated multiple-input converters from the single-input versions in [11]-[13], which are adopted to identify the feasible input cell that complies with some assumptions and conditions. The common feature of the aforementioned multiport converters is that the energy management or the control scheme is part coupled or inter restrictive. Another universal solution to generate multiport converters is to combine the dc-link configuration and adopt the magnetic coupling solution [14]-[19]. Half-bridge structure, full-bridge structure, and their integration can be employed to satisfy some stringent requirements.

The clear advantages of the fully coupled multiport converters are zero-voltage switching (ZVS) operation, easy energy management, and flexible configuration. In order to improve the device sharing ratio among different ports, realize soft-switching operation, and achieve decoupled control within a certain operating range, a novel PWM plus phase angle shift (PPAS) control scheme is proposed. In this Phase-shift control scheme or pulse width modulation (PWM) plus phase shift control strategy is usually used in these cases. Furthermore, series resonance control scheme can be also employed [20]. However, the variable frequency operation increases the Electro Magnetic Interference (EMI) filter design difficulty. MLI analyses for various system [28-37]. The main limitation of the fully coupled multiport converters is that a lot of power devices are required because each port cannot share the same power switches. In order to improve the device sharing ratio among different ports, realize soft-switching operation, and achieve decoupled control within a certain operating range, a novel PWM plus phase angle shift (PPAS) control scheme is used in this paper. 


\section{Circuit Description}

The full bridge converter are integrated to generate a combined three port converter for the PV-PV hybrid energy system, which is used as an example to show the operation

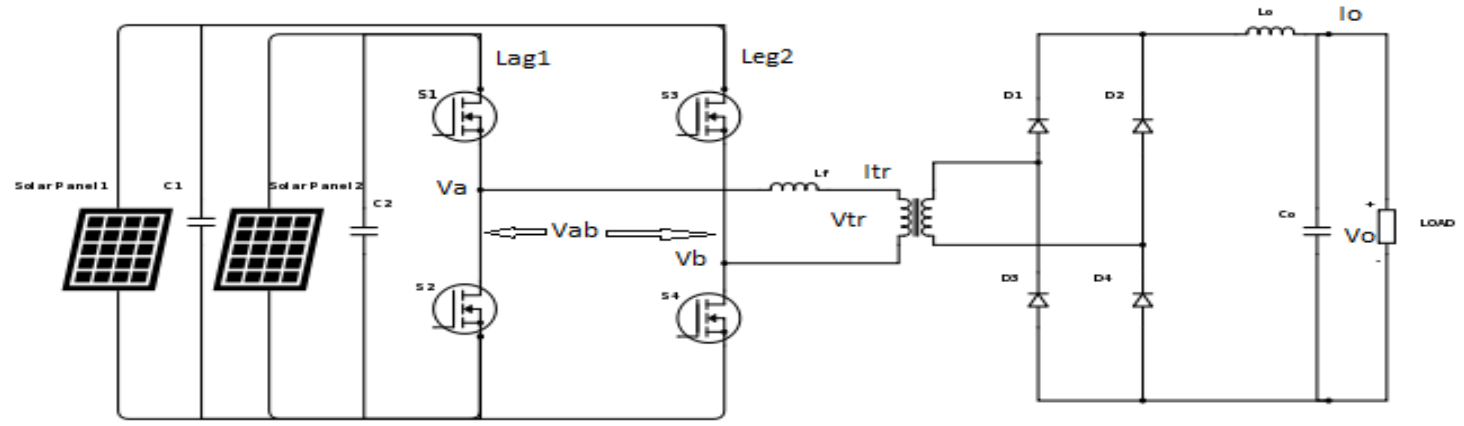

(a)

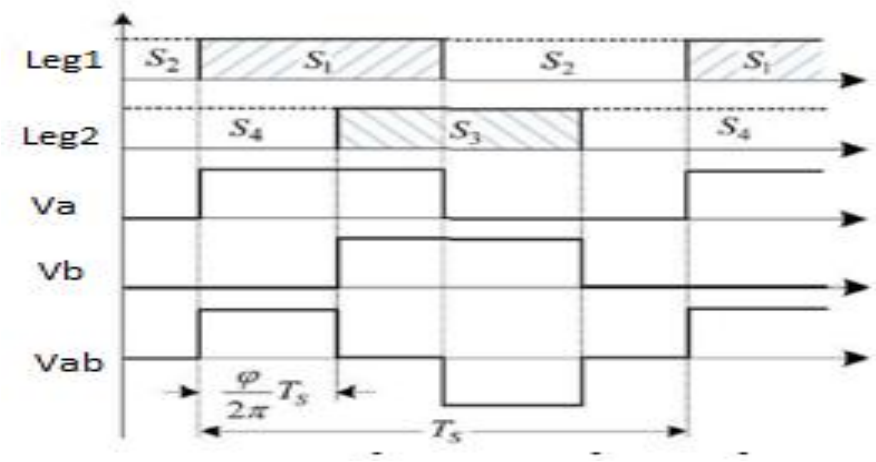

(b)

Fig. 1: PPAS control scheme. (a) Full bridge DC-DC converter.

(b) Key steady-state waveforms

principle of the PPAS control scheme. Furthermore, the phase angle control is employed as another control freedom to regulate the secondary output voltage. As a result, great control flexibility is provided.

The above literature does not deal with comparison of PI \& FL controlled DDCDM systems. This work proposes FLC for the control of DDCDCM system. A T filter is suggested at the output of DC to DC converter to reduce the ripple.

\section{Simulation Results}

Simulation is done for open loop and closed loop systems with PI $\&$ FL controllers. The simulation results are presented in this section.

\section{(i) Results of open loop DDCDCM system}

Circuit diagram for DC-DC converter system is shown in Fig 4. The output of DDC is applied to the DC motor. The output voltage of solar system is shown in Fig 5 and its value is $12.5 \mathrm{~V}$.

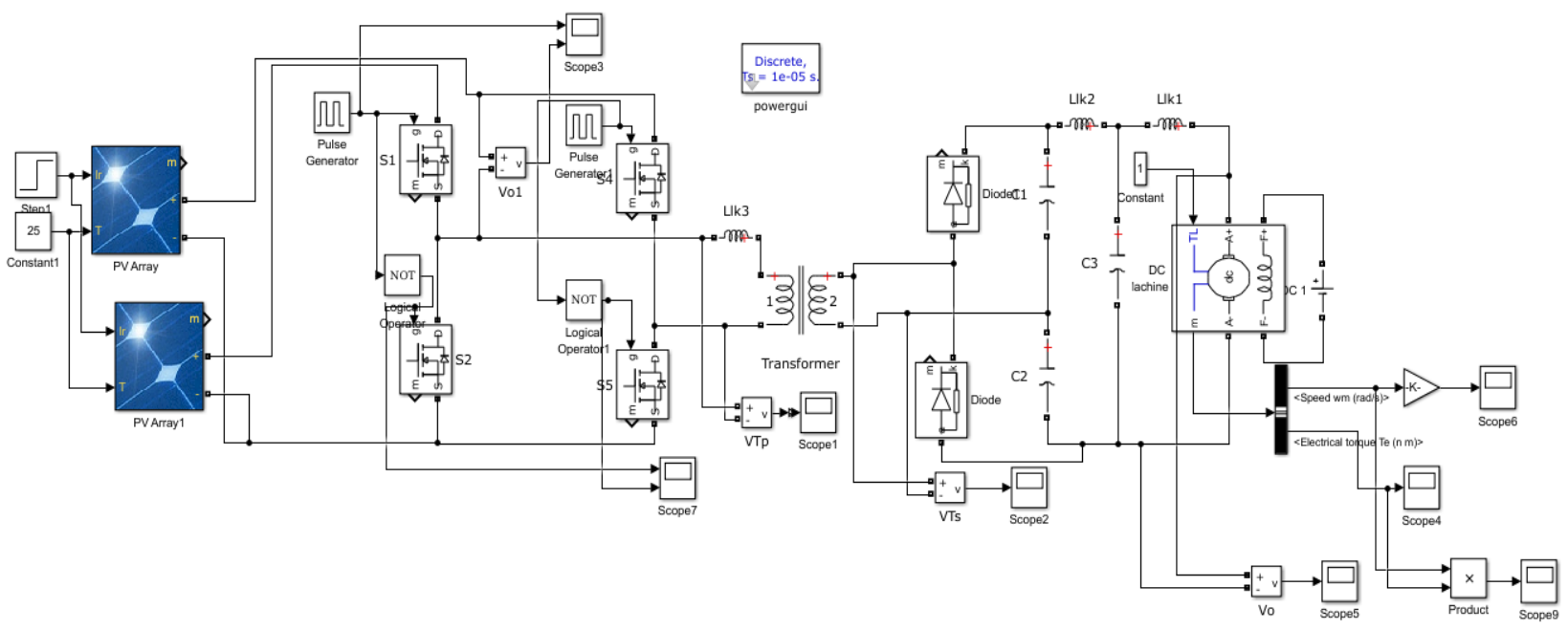

Fig. 4: Circuit diagram for DC-DC converter 


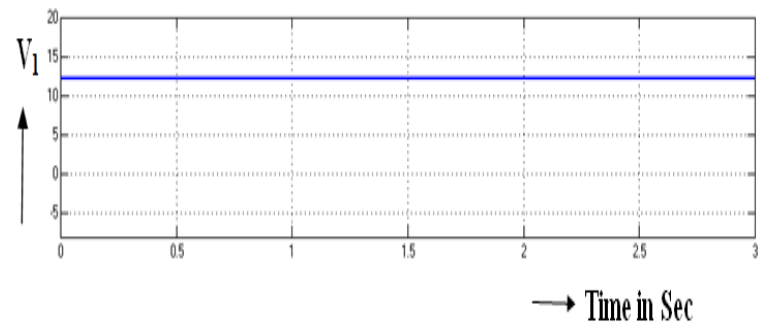

Fig. 5: Output voltage of solar1

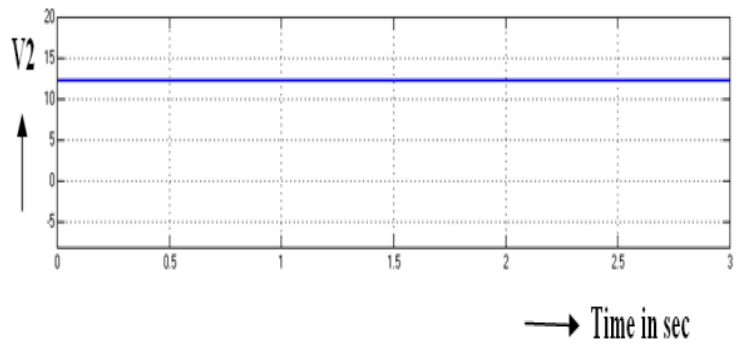

Fig. 6: Output voltage of solar 2

The primary Voltage of transformer is shown in Fig. 7 and its peak value is $15 \mathrm{~V}$. The output voltage is shown in Fig. 8 and its value is $60 \mathrm{~V}$.

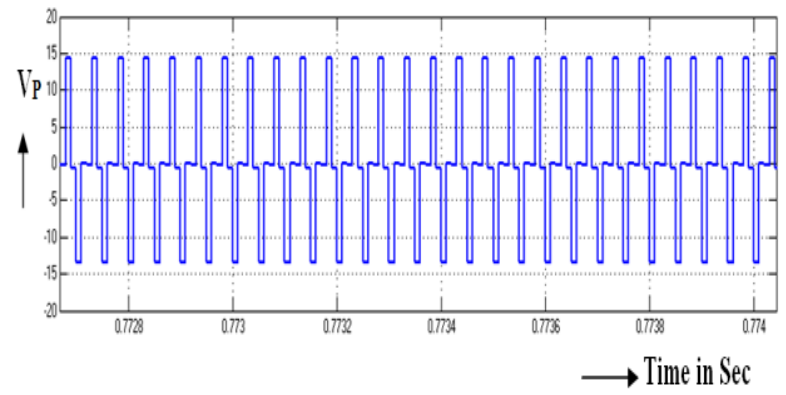

Fig. 7: Primary Voltage of Transformer

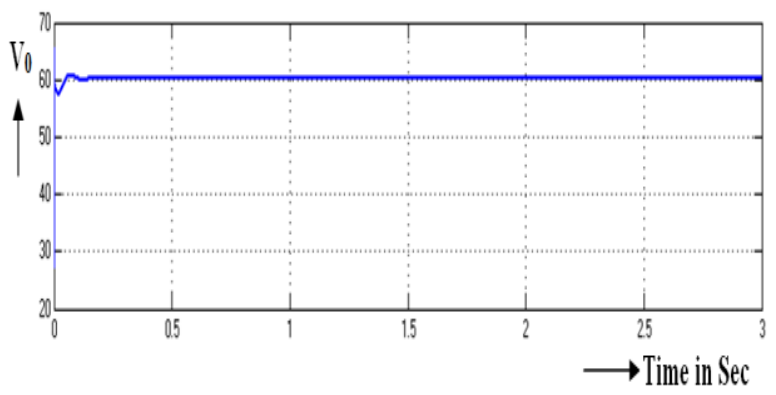

Fig. 8: Output voltage

The motor speed is shown in Fig. 9 and its value is $400 \mathrm{rpm}$. The Torque response is shown in Fig. 10 and its value is $2 \mathrm{Nm}$.

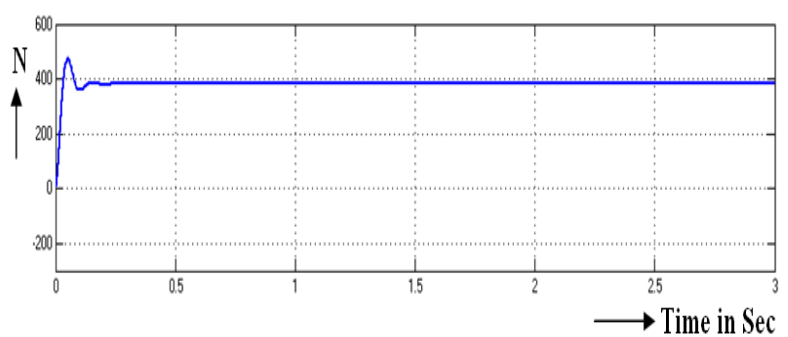

Fig. 9: Motor speed

The output power is shown in Fig. 11 and its value is $70 \mathrm{~W}$. The summary of output voltage ripple, power and speed for different value of load torque are shown in Table 1 . The speed and ripple decrease with the increase in load torque.

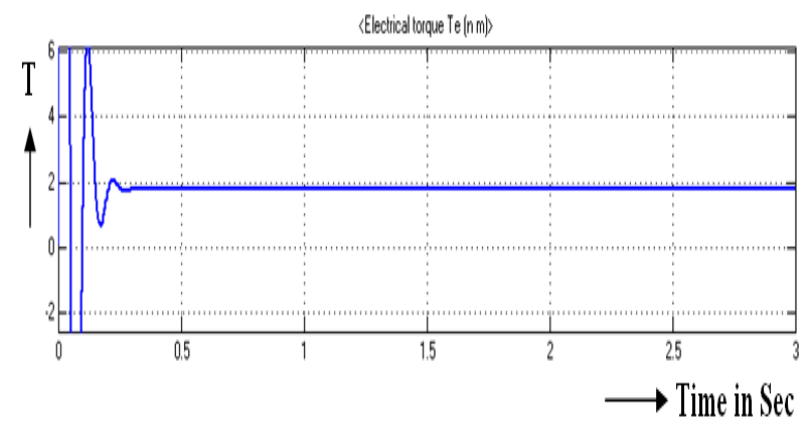

Fig. 10: Torque Response

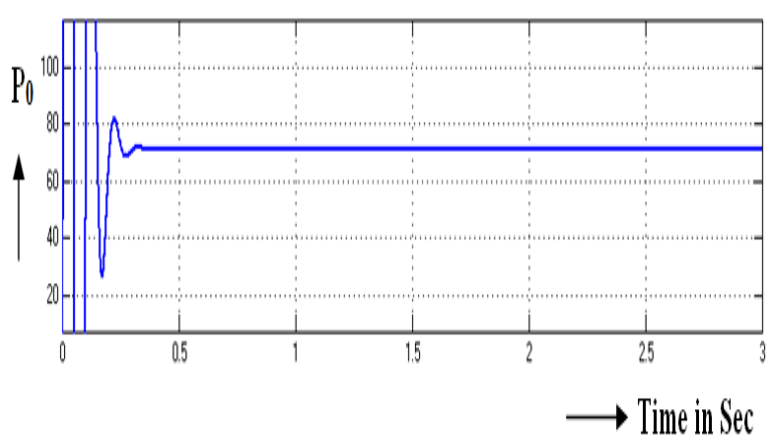

Fig. 11: Output power

Table 1: Comparison of Output Voltage Ripple, Speed and Output power for various value of load torque

\begin{tabular}{|l|l|l|l|}
\hline TL & N(RPM) & Po & $\begin{array}{l}\text { Voltage } \\
\text { ripple }\end{array}$ \\
\hline 1 & 379 & $70 \mathrm{w}$ & $0.06 \mathrm{v}$ \\
\hline 2 & 376 & $110 \mathrm{w}$ & $0.05 \mathrm{v}$ \\
\hline 3 & 374 & $148 \mathrm{w}$ & $0.04 \mathrm{v}$ \\
\hline 4 & 372 & $186 \mathrm{w}$ & $0.03 \mathrm{v}$ \\
\hline
\end{tabular}

\section{(ii). Closed loop DDCDCM with PI Controller}

Closed loop system with PI controller is shown in Fig. 12. Actual speed of DC motor is compared with the reference speed and the error is applied to the PI controller. The output of PI is compared with the saw tooth to produce updated pulses for the rectifier. The input voltage is shown in Fig. 13 and its value increases from 12 to $17 \mathrm{~V}$. 


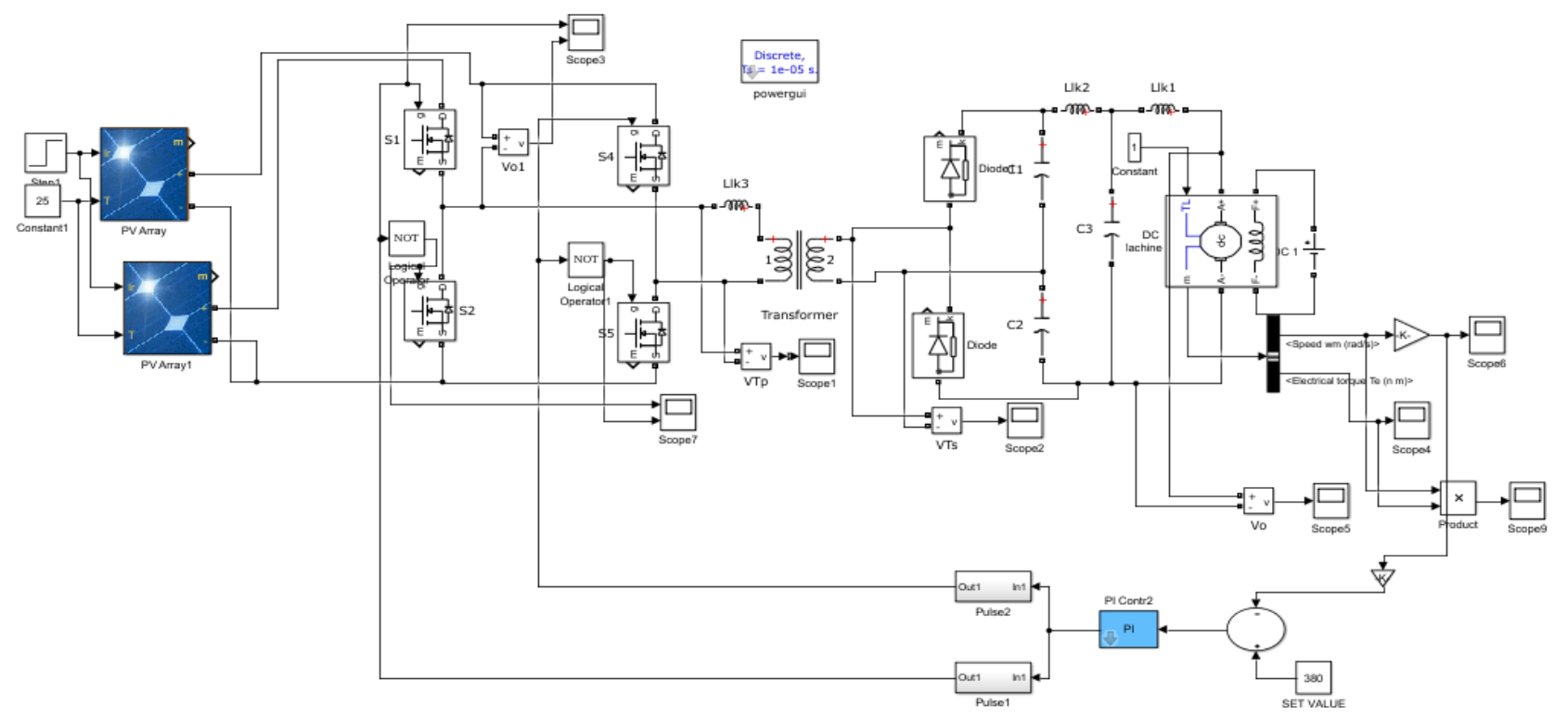

Fig. 12: Closed loop DDCDCM system with PI controller

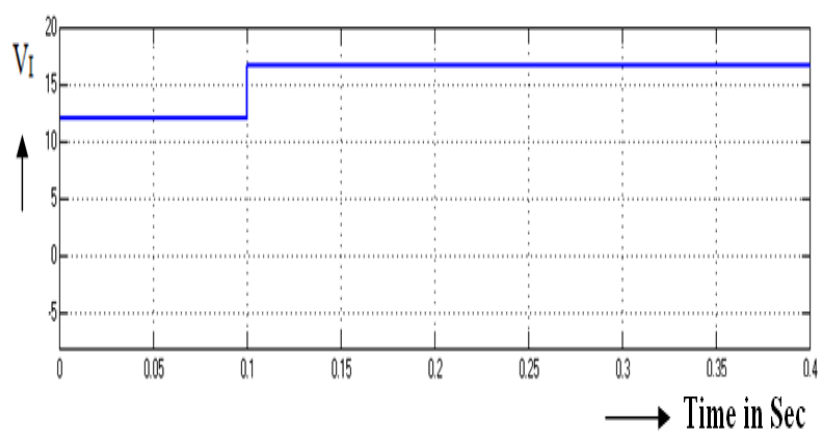

Fig. 13: Input voltage

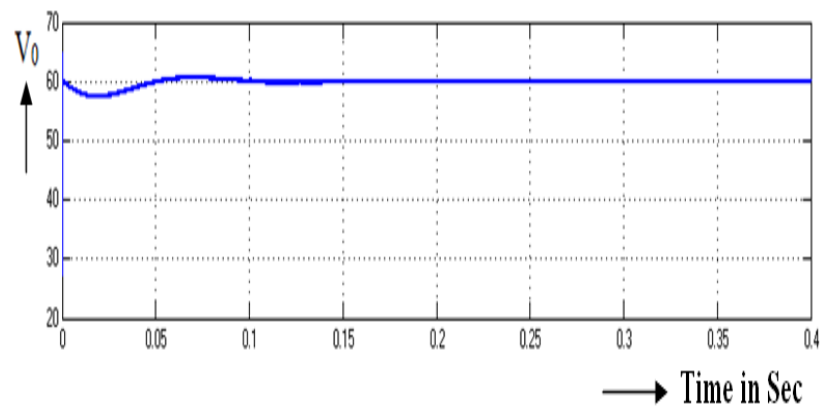

Fig. 14: Output voltage

The output voltage is shown in Fig. 14 and its value is $60 \mathrm{~V}$. The motor speed is shown in Fig. 15 and its value is $382 \mathrm{rpm}$. It can be seen that the speed is almost equal to the set value. The Torque response is shown in Fig. 16 and its value is $2 \mathrm{Nm}$. The output power is shown in Fig. 17 and its value is $80 \mathrm{~W}$.

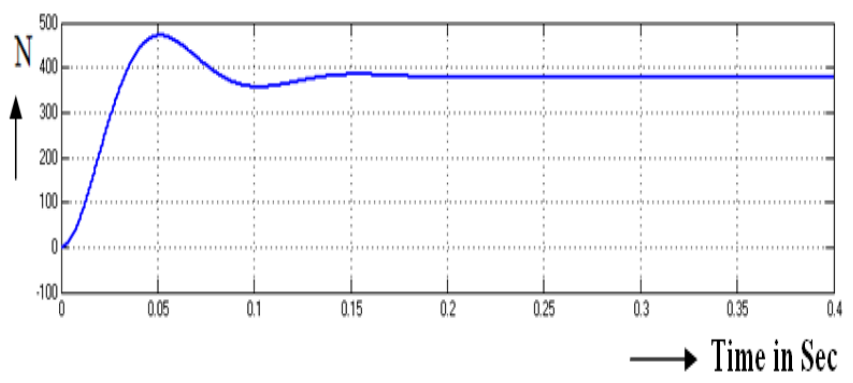

Fig. 15: Motor speed

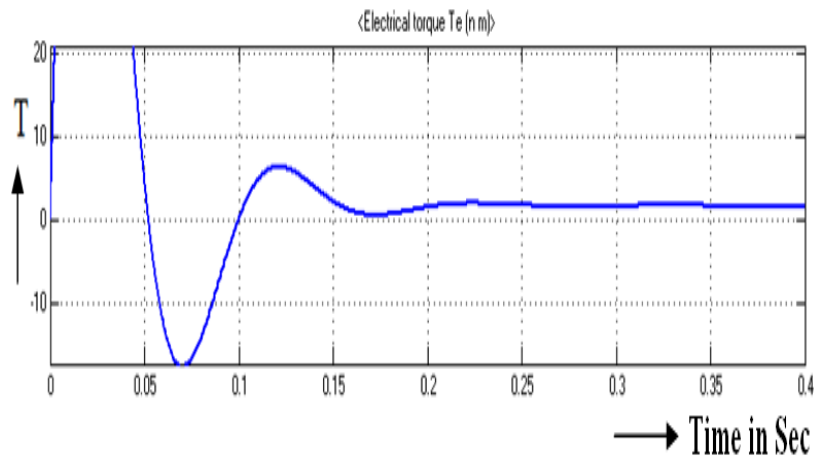

Fig. 16 :Torque Response

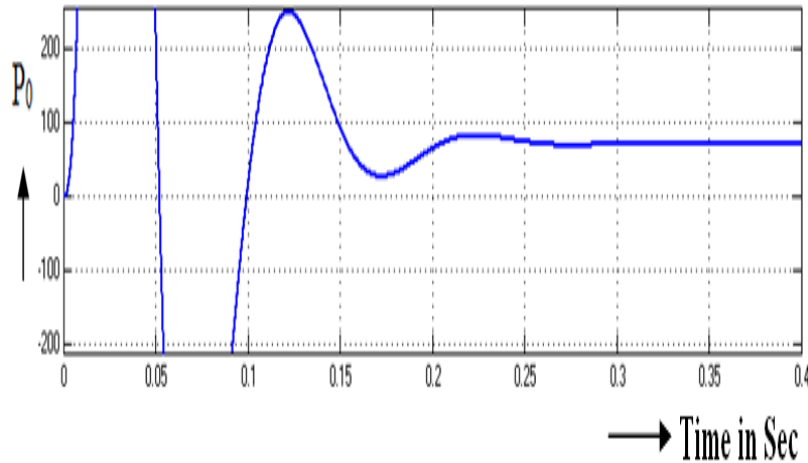

Fig. 17: Output power

Closed loop DDCDCM system with FL controller is shown in Fig. 18. The PI controller is now replaced by FLC. The output voltage is shown in Fig. 19 and its value is $60 \mathrm{~V}$. The motor speed is shown in Fig. 20 and its value is $400 \mathrm{rpm}$. The Torque response is shown in Fig. 21 and its value is $2 \mathrm{Nm}$. 


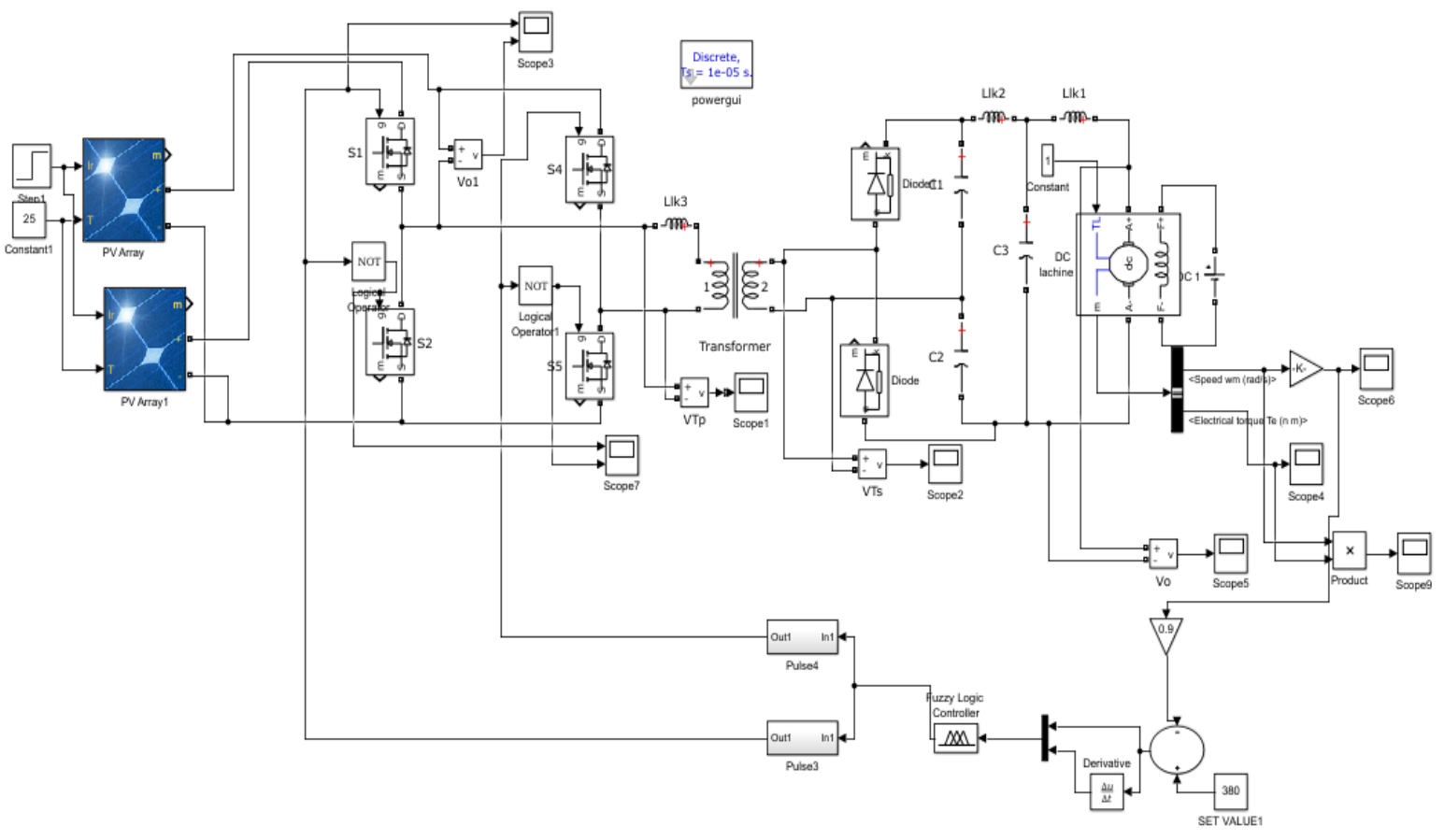

Fig. 18: Proposed FLCDDCDCM System

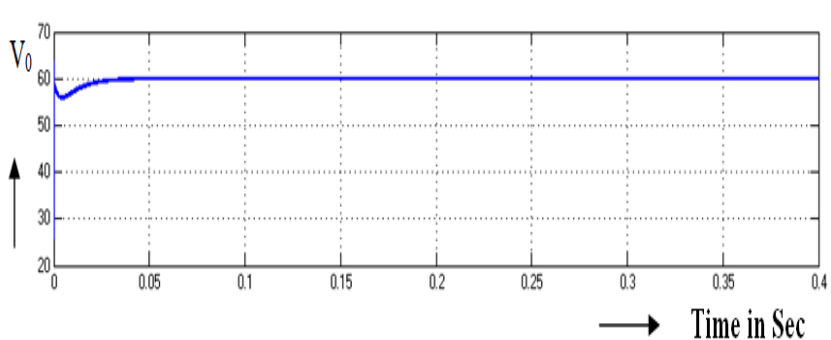

Fig. 19: Output Voltage

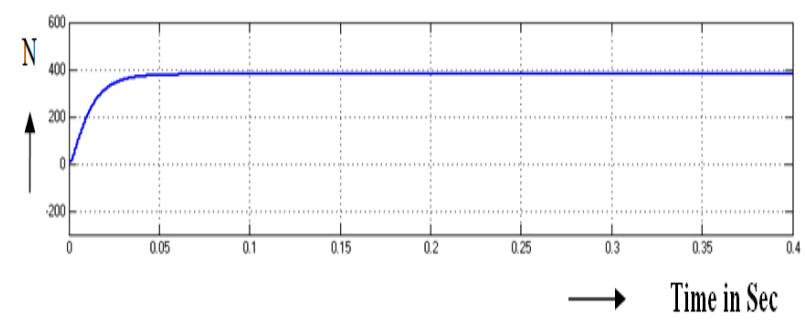

Fig. 20: Motor speed

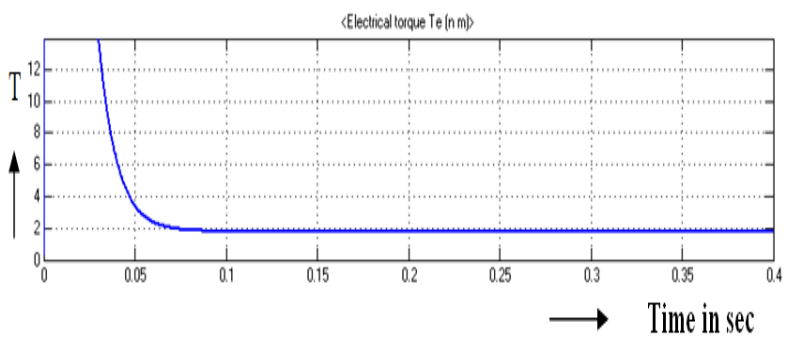

Fig. 21: Torque Response

The output power is shown in Fig. 22 and its value is $75 \mathrm{~W}$. The comparison of time domain parameters with PI \& FLC is shown in Table 2. Rise time is reduced from 0.13 to $0.04 \mathrm{Sec}$. The settling time is reduced from 0.2 to $0.05 \mathrm{Sec}$. Peak time is reduced from 0.12 to 0.03 Second steady state error in speed is reduced from 2.1 to 0.5 RPM by using FLC. It can be seen that the response with FLC is superior to PI controlled system since the steady state error $\&$ settling time are reduced.

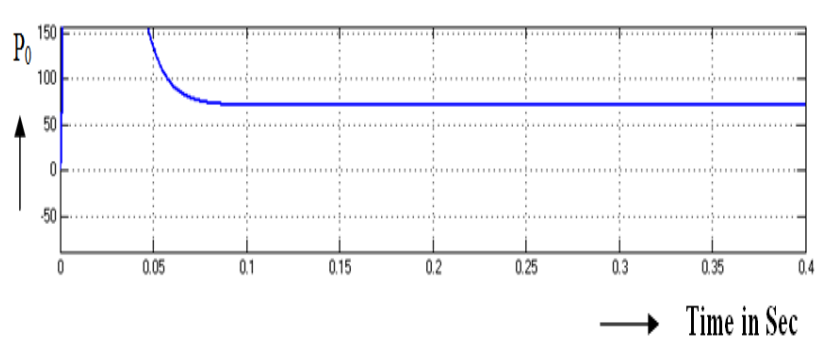

Fig. 22: Output power

Table 2: Comparison of Time Domain Parameters with PI \& FLC

\begin{tabular}{|l|l|l|l|l|}
\hline $\begin{array}{l}\text { Type of of } \\
\text { Controller }\end{array}$ & $\begin{array}{l}\mathbf{t}_{\mathbf{r}} \\
\text { sec }\end{array}$ & $\begin{array}{l}\mathbf{t}_{\mathbf{s}} \\
\text { sec }\end{array}$ & $\begin{array}{l}\mathbf{t}_{\mathbf{p}} \\
\text { sec }\end{array}$ & $\begin{array}{l}\mathbf{E}_{\text {ss }} \\
\text { RPM }\end{array}$ \\
\hline PI & 0.13 & 0.2 & 0.12 & 2.1 \\
\hline FLC & 0.04 & 0.05 & 0.03 & 0.5 \\
\hline
\end{tabular}

\section{Experimental Results}

The hardware for prototype DDCDCM is fabricated and tested. The hardaware Snap shot is shown in Fig. 23. The hareware consists of PV panel, battery, control board, converter board and DC motor. The output voltage of solar system is shown in Fig. 24. Switching pulses for M1 \& M3 are shown in Fig. 25. Primary voltage across transformer is shown in Fig. 26 and secondary voltage is shown in Fig. 27. DC output voltage of DDC is shown in Fig. 28. 

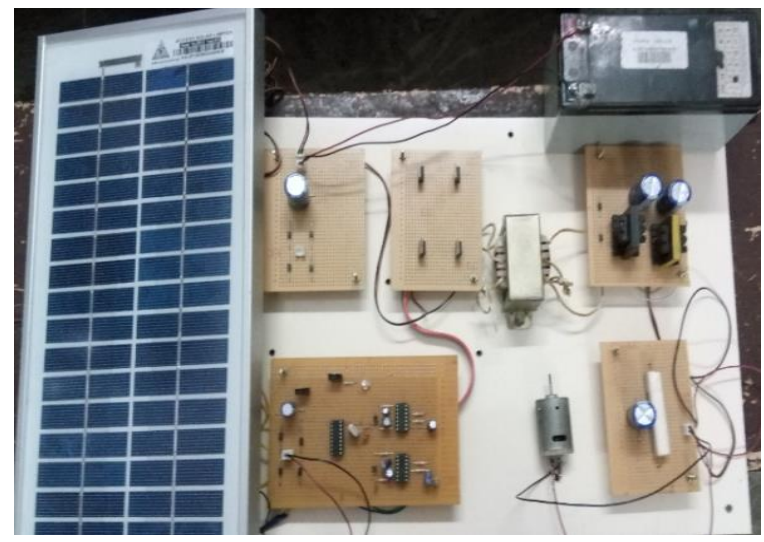

Fig. 23 : Hardware snap shot of DDCDCM

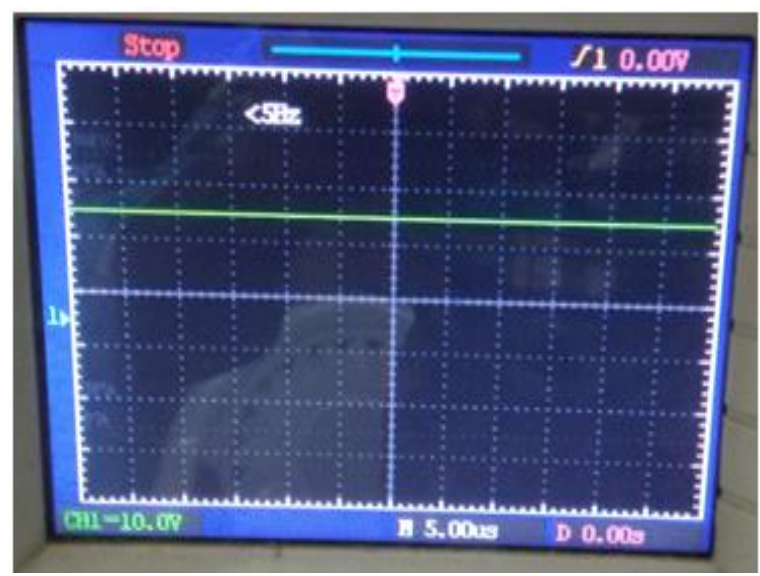

Fig. 24: Output voltage of solar system

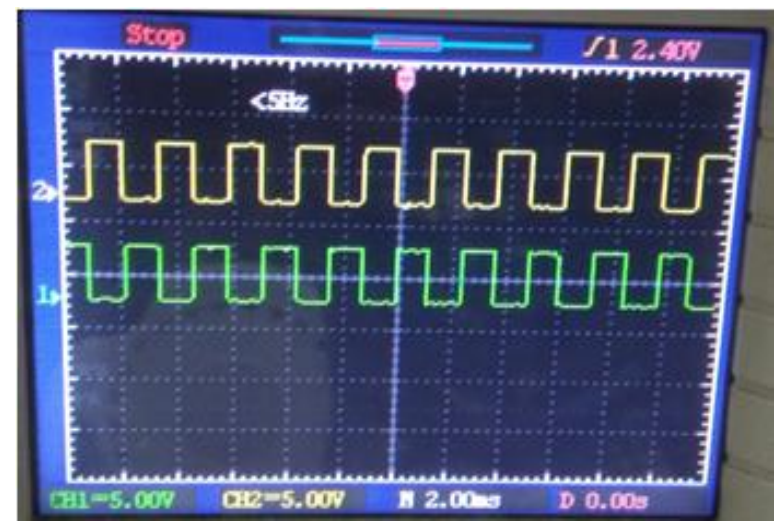

Fig. 25: Switching pulses for M1 \& M3

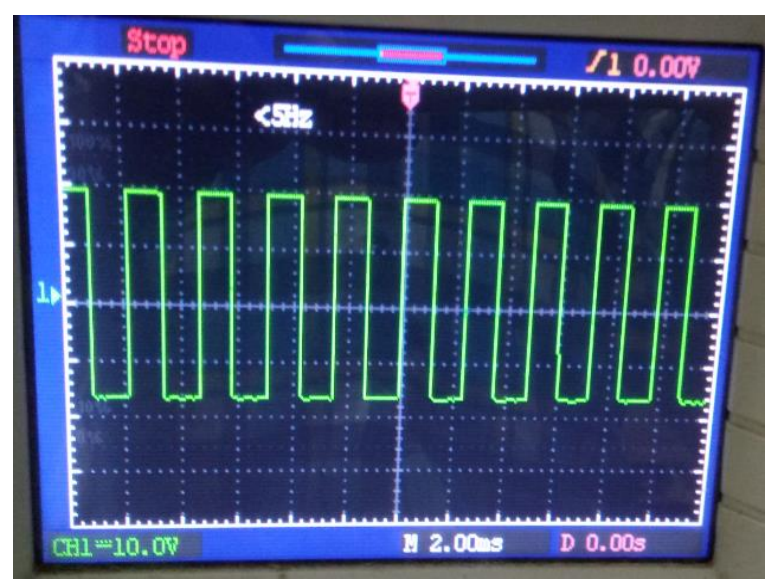

Fig. 26: Primary voltage of Transformer

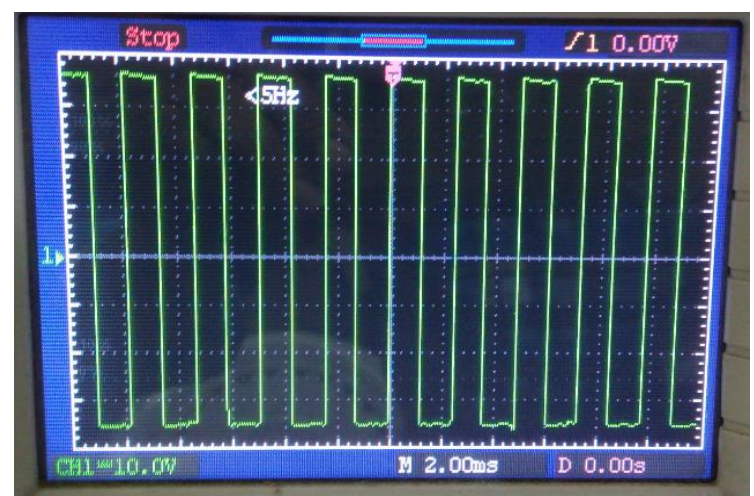

Fig. 27: Secondary voltage of Transformer

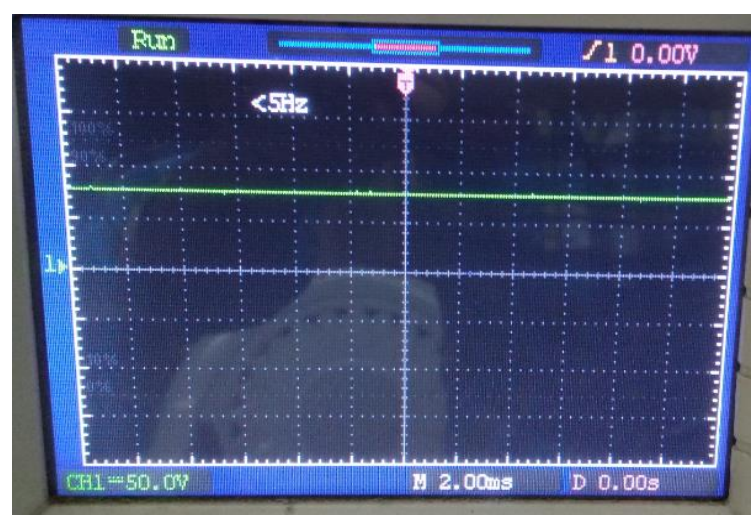

Fig. 28: Output voltage

\section{Conclusion}

Closed loop PI \& FL controlled DC to DC converter Fed DC Drive systems are successfully modeled and simulated. The results of DDCDCM with PI \& FLC are compared. The results indicate that the responses with FLC are superior to PI controlled system. The settling time is as low as 0.05 sees and the steady state error in speed is $0.5 \mathrm{~V}$. The prototype hardware is fabricated and tested. The experimental results are similar to the simulation results. Proposed FLC DDCDCM needs small transformer and small filter.

The present work deals with comparison of responses with PI \& FL controllers. The comparison between PI \& FOPID controlled DDCDCM systems will be done in future.

\section{References}

[1] Q. Li and P. Wolfs, "A review of the single phase photovoltaic module integrated converter topologies with three different DC link configurations," IEEE Transactions on Power Electronics, Vol. 23, No. 3, pp. 1320-1333, May 2008.

[2] J. Selvaraj and N. A. Rahim, "Multilevel inverter for gridconnected PV system employing digital PI controller," IEEE Transactions on Industrial Electronics, Vol. 56, No. 1, pp. 149158, Jan. 2009.

[3] L. Solero, A. Lidozzi, and J. A. Pomilio, "Design of multipleinput power converter for hybrid vehicles," IEEE Transactions on Power Electronics, Vol. 20, No. 5, pp. 1007-1016, Sep. 2005.

[4] Ferreira, J. A. Pomilio, G. Spiazzi, and L. de Araujo Silva, "Energy management fuzzy logic supervisory for electric vehicle power supplies system," IEEE Transactions on Power Electronics, Vol. 23, No. 1, pp. 107-115, Jan. 2008.

[5] G. Dobbs and P. L. Chapman, "A multiple-input DC-DC converter topology," IEEE Power Electronics Letter, Vol. 1, No. 1, pp. 6-9, Mar. 2003.

[6] N. D. Benavides and P. L. Chapman, "Power budgeting of a multiple input buck-boost converter," IEEE Transactions on Power Electronics, Vol. 20, No. 6, pp. 1303-1309, Nov. 2005. 
[7] Khaligh, J. Cao, and Y. J. Lee, "A multiple-input DC-DC converter topology," IEEE Transactions on Power Electronics, Vol. 24, No. 3, pp. 862-868, Mar. 2009.

[8] Al-Atrash, F. Tian, and I. Batarseh, "Tri-modal half-bridge converter topology for three-port interface," IEEE Transactions on Power Electronics, Vol. 22, No. 1, pp. 341-345, Jan. 2007.

[9] Z. Qian, O. Abdel-Rahman, H. Al-Atrash, and I. Batarseh, "Modeling and control of three-port DC/DC converter interface for satellite applications," IEEE Transactions on Power Electronics, Vol. 25, No. 3, pp. 637-649, Mar. 2010

[10] Z. Qian, O. Abdel-Rahman, and I. Batarseh, "An integrated four-port DC/DC converter for renewable energy applications," IEEE Transactions on Power Electronics, Vol. 25, No. 7, pp 1877-1887, Jul. 2010

[11] Kwasinski, "Identification of feasible topologies for multipleinput DC-DC converters," IEEE Transactions on Power Electronics, Vol. 24, No. 3, pp. 856- 861, Mar. 2009

[12] Y. Li, X. Ruan, D. Yang, F. Liu, and C. K. Tse, "Synthesis of multiple input DC/DC converters," IEEE Transactions on Power Electronics, Vol. 25, No. 9, pp. 2372-2385, Sep. 2010.

[13] Y. C. Liu and Y. M. Chen, "A systematic approach to synthesizing multi-input DC-DC converters," IEEE Transactions on Power Electronics, Vol. 24, No. 1, pp. 116-127, Jan. 2009.

[14] Liu and H. Li, "A ZVS bi-directional DC-DC converter for multiple energy storage elements," IEEE Transactions on Power Electronics, Vol. 21, No. 5, pp. 1513-1517, Sep. 2006.

[15] G. J. Su and L. Tang, "A multiphase, modular, bidirectional, triple-voltage DC-DC converter for hybrid and fuel cell vehicle power systems," IEEE Transactions on Power Electronics, Vol. 23, No. 6, pp. 3035-3046, Nov. 2008.

[16] J. L. Duarte, M. A. M. Hendrix, and M. G. Godoy, "Three-port bidirectional converter for hybrid fuel cell systems," IEEE Transactions on Power Electronics, Vol. 22, No. 2, pp. 480-487 Mar. 2007.

[17] H. Tao, J. L. Duarte, and M. A.M. Hendrix, "Three-port triplehalf-bridge bidirectional converter with zero-voltage switching," IEEE Transactions on Power Electronics, Vol. 23, No. 2, pp 782-792, Mar. 2008.

[18] H. Tao, A.Kotsopoulos, J. L.Duarte, and M.A.M.Hendrix, "Transformer coupled multiport ZVS bidirectional DC-DC converter with wide input range," IEEE Transactions on Power Electronics, Vol. 23, No. 2, pp. 771-781, Mar. 2008.

[19] Zhao, S.D.Round, and J.W.Kolar, "An isolated three-port bidirectional DC-DC converter with decoupled power flow management," IEEE Transactions on Power Electronics, Vol. 25, No. 5, pp. 2443-2453, Sep. 2008.

[20] H. Krishnaswami and N. Mohan, "Three-port series-resonant DC-DC converter to interface renewable energy sources with bidirectional load and energy storage ports," IEEE Transactions on Power Electronics, Vol. 24, No. 10, pp. 2289-2297, Oct. 2009

[21] H. Al-Atrash, M. Petter, and I. Batarseh, "A zero-voltage switching three port isolated full-bridge converter," IEEE International Telecommunication Energy Conference, 2006, pp. $1-8$.

[22] [H. Al-Atrash and I. Batarseh, "Boost-integrated phase-shift fullbridge converter for three-port interface," IEEE Power Electronics Specialists, pp. 2313-2321, 2007.

[23] R. Kadri, J. P. Gaubert, and G. Champenois, "An improved maximum power point tracking for photovoltaic grid-connected inverter based on voltage-oriented control," IEEE Transactions on Industrial Electronics, Vol. 58, No. 1, pp. 66-75, Jan. 2011.

[24] Safari and S. Mekhilef, "Simulation and hardware implementation of incremental conductance MPPT with direct control method using Cuk converter," IEEE Transactions on Industrial Electronics, Vol. 58, No. 4, pp. 1154-1161, Apr. 2011.

[25] O. Lopez-Lapena, M. T. Penella, and M. Gasulla, "A new MPPT method for low-power solar energy harvesting," IEEE Transactions on Industrial Electronics, Vol. 57, No. 9, pp. 3129 3138, Sep. 2010.

[26] Yang, W. Li, Y. Zhao, and X. He, "Design and analysis of a grid connected PV power system," IEEE Transactions on Power Electronics, Vol. 25, No. 4, pp. 992-1000, Apr. 2010.

[27] W. Li, Y. Zheng, W. Li, Y. Zhao, and X. He, "A smart and simple PV charger for portable applications," in Proc. IEEE Applied Power Electronics Conference Exposition, 2010, pp 2080-2084.
[28] R.Umamageswari, C.R.Balamurugan, "Analysis And Design Control Of Smart Dc Microgrid For Integration Of Renewable Energy Sources", International Journal of Electrical and Electronics Engineers, ISSN: 2321-2045, vol.9, no.2, pp.177185, Dec 2017.

[29] S.M.Revathi, C.R.Balamurugan, "A Review on Various ZSource Fed Multilevel Inverter", International Journal of Electrical and Electronics Engineers, ISSN: 2321-2045, vol.9, no.2, pp.152-161, Dec 2017.

[30] R.Umamageswari, C.R.Balamurugan, T.A.Ragavendiran "Fuzzy Logic Controlled Cascaded Buck Boost Converter Using Multilevel Inverter System", Journal of Computational and Theoretical Nanoscience, ISSN: 1546-1955 (Print): EISSN: 1546-1963 (Online), vol.14, no.6, pp. 2666-2672, June 2017.

[31] T.Vishnu, C.R.Balamurugan, C.Tony Roy, "Hologram Based Three Dimensional Projection", International Journal of Engineering Technology Science and Research, ISSN $2394-$ 3386, Vol. 4, No. 8, pp. 341- , 346, August 2017.

[32] R.Srinivasan, C.R.Balamurugan, "A Review on Various Renewable Energy Sources", International Journal of Electronics, Electrical and Computational System, ISSN 2348117X, Vol. 6, No. 8, pp.221-235, August 2017.

[33] M.SanthoshKumar, C.R.Balamurugan, "A detailed review on self propelled safety monitoring system using can protocol, World Journal of Modelling and Simulation, ISSN No. 17467233. vol. 13, no.3, pp. 228-240, August 2017

[34] C.R.Balamurugan, R.Satheesh, "Development of Raspberry pi and IoT Based Monitoring and Controlling Devices for Agriculture, Fronteiras: Journal of Social, Technological and Environmental Science, ISSN No. 2238- 8869. vol. 6, no.2, pp. 207-215, August 2017. (Scopus Indexed)

[35] C.R.Balamurugan, K.Vijayalakshmi, "Investigations on ZSource Based Three Level Inverter", International Journal of Control and Automation, ISSN No. 2005-4297, vol.10, no.9, pp.15-26, September 2017.

[36] S.Balaji Venkatraman, C.R.Balamurugan, "Remedial Measures for the Impact of Deviation in Natural Resources", International Journal of Mathematical and Computational Methods, ISSN No. 2367-895X, vol.2, pp. 243-248, 2017.

[37] C.R.Balamurugan, R.Bensraj, "Hardware realization self propelled safety monitoring system using CAN protocol" Journal of Engineering Science and Technology, ISSN No. 1823-4690, vol.13, no.1, pp. 83 - 101, Jan 2018. 